\title{
Political Economy of Coal Mining Policy: A Case Study in Rent Seeking of Surveyor's Data Manipulation in East Kalimantan (2009-2014)
}

\author{
Bambang Arwanto
}

barwanto@ugm.ac.id

\author{
Received: Aug. 9, 2018 Accepted: Oct. 4, 2018 Online published: Oct. 23, 2018 \\ doi:10.5296/jpag.v8i4.13819 URL: https://doi.org/10.5296/jpag.v8i4.13819
}

\begin{abstract}
Both rent seeking and mining policy are two interesting discourses which have enriched the Indonesian policy studies within last two decades. One of prominent problems in this sector is formulation policy process of mining permit (IUP). The concern of mining sector is because the huge economic incentive behind mining business including coal mining. Since the economic incentive is extremely high, the rent seeking is getting higher and more competitive. The competition on rent seeking contest is developed in different policy formulation stages through the elites of business people and bureaucrats.

The consequences are the objectivity on issuing the coal mining policy, including extra regulation about surveyors. The policy formulation in this very case produces the dynamic and complex rent seeking activity among the main players. This study is aimed to reveal the case of rent seeking using surveyors on coal mining policy. Using qualitative method and non positivist approach, this case of study was one of five studies that tried to understand the social relationship among the policy actors during mining policy formulation.

Findings in the study were: (i) the role of surveyors as "third person" as mediator who played prominent roles in delivering the interest and determined the data through surveyor's report, (ii) bargaining power of the businessman to get access in penetrating the bureaucracy through bribing and lobbying, and (iii) the role of bureaucrat in manipulating regulation to accommodate their interest through extra regulation making.
\end{abstract}

Keywords: East Kalimantan, coal mining permit, elites, political economy, rent seeking, surveyor

\section{Introduction}

Mining policy has constituted a very interesting discourse since the energy is one of the 
prominent global issues so that the global world puts the same agenda on sustainable energy. In Indonesia the biggest reason on why this issue considered important is because of its economical incentive as point of interest. More specificly, in term of policy formulation and agenda setting of mining concession, it is widely understood that one of greatest problem is the conflict of interest among policy actors. ${ }^{1}$

Rent seeking and mining policy are two interesting discourses that have enriched the Indonesian policy studies within last two decades. One of prominent problems in this sector is the authority in which government took part in formulating policy of mining permit (IUP). This concern is because there is a huge economic incentive behind mining bussiness and coal mining business. Since the economic incentive is extremely high, the rent seeking is getting higher and more competitive. The competition on rent seeking contest is developed also in formulation stage and agenda setting through the elites of business people and bureaucrats.

The considerable huge economic profit in managing coal mining business becomes one of reasons why rent's contestation is dynamic in this subsector. ${ }^{2}$ The role and interest of those policy elites put the exploration and permit in the real economic war by struggling in obtaining exploration permit from the government. One of the prominent ways is the lobby among stakeholders to have privilege inside of government in term of exploration. The result of this war is the fact that in turn coal mining policy is just merely a tool for different actors from local and central government to possess the better privilege to get rents. ${ }^{3}$ During the period of 2009-2014 is the time when the price of international coal was extremely promising. This price booming become the main reason for dispute of policy by corporation actor and bureaucracy elites ${ }^{4}$.

The consequences are the objective of the mining permit turns to be self profit and self interest. The policy formulation in this case produces the dynamic and complex rent seeking activity among the main players. This study is aimed to reveal the case of rent seeking using surveyors on coal mining policy formulation. Using qualitative method and non positivist approach, this study tried to understand the social relationship among the policy actors around the Data manipulation of surveyor's on coal mining policy, Certain interest emerges from different kind of group namely business group, non-governmental organization, academics, and also bureaucracy. Since the policy can be taken as output in economic logic as contestation of supply and demand in rational way. Contrary, interest of individuals and group interest provide the biases in policy output. The dynamic of interest turns the policy formulation into a very complicated process and different way from the simplicity of steps in

\footnotetext{
1 The Law of Mineral and Coal Mining Number 4/2009 mentioned that central government has an authority to issues permits as Coal Mining Agreement (PKP2B). It must be adjusted with Mining Consession (MC) or Izin Usaha Pertambangan (IUP) which issued by local government in one year after being legalized as a national act. Recently, there is no such adjusment to occur (PKP2B to IUP). Evenmore, that dualism of permit has made conflict.

${ }^{2}$ In this context, the term of rents refer to the term in natural resource rents according to Jomo and Khan (2000: 2)

3 Tool of policy to achieve rents was policy CNC. The consession of IUP was named as "Clear and Clean" (CNC), by issuing Decree (SK) Number 1406/30/DJB/2012 dated 30 April 2012 about "Standard Operating Procedure (SOP) on the processing of Clear and Clean standard.

${ }^{4}$ The 2009 period of permits decentralization based on the law of mineral and coal mining (minerba), but during the booming, the dynamic on coal price causes elites change the rule from decentralization to centralization according to the Law of Local Government Number 23/2014.
} 
"policy cycle".

This complexity is simply caused by reasonable number of policy actors and institutions. An actor can be having hard struggle in achieving his or her agenda against public value. Some actors play the role as representatives of group namely mining business association, Jatam (mining network advocation), and surveyor. The role of surveyor is important as a representative of government in verifying export products. In general, during the policy formulation, the sole way people get in charge of the eight rent-seeking activities is the need to gain privilege from government through the easiness to get regulation access (Parker, 2011).

The study is organized to reveal the real interest of those policy agendas. That is the manipulation through data and number (mark up and mark down) by surveyor in the name of rent-seeking interest is exploited by using self-assessment method in verifying coal export. This manipulation potentially causes the loss of 14 trillion rupiah of state revenue (KPK, 2013); since the central government can not be able to provide data and number by real time to control the number of coal export. In the other hand the local government also losses the opportunity of check and balance by the abolishment of Reference of Commodity Origin (SKAB) by The Ministry of Energy and Mineral Resources of the Republic of Indonesia. The presence study tries to reveal how the role surveyors are being made as the third person to facilitate the agenda of interest. This role would reform the certain rent seeking patron and determine the decision in formulating policy process in mining sector of East Kalimantan Province. Later on, the other fact "penguasa-pengusaha" (person with higher authority-business person) phenomenon is deeply explored as well.

In term of rent-seeking we do agree to use the concept of action of how the business people would gain benefit through policy actors. This study emphasizes on how the dynamic and relationship among the actors and mining policy process mainly surveyors' activity as well. This comes from the interest of the policy makers that bring about the neutrality. The neutrality then brings the policy output to accommodate the elite interest through policy actors. The action of rent-seeking by policy actors is also part of elites who manipulate regulation. One of the methods is exploited the regulation of using data from the surveyors.

In term of political interest, the most important difference between political economy and conventional economy is the insight in term of power structure among society. Political economy perspective ensures that the power structure is affected by economic achievement. Meanwhile the conventional economy considers that the power structure is something given (Yustika, 2011: 2). It is clearly explained by Laswell (in Parsons, 2008: 17) that policy will determine what is considered as the most important that is chosen by organization or private so that it must be free from the political connotation that tends to have its own meaning in term of "interest" and "corrupted".

Approach in political economy on policy study mostly emphasizes the dynamic of state and market role. In this context, the state has an ability to intervene the market so that certain sectors will not solely conform to the market mechanism. This intervention through policy will allow the state to force the market so that certain policy will consistently put the public 
value as the top priority. This value is considered important to accommodate public interest as ruled by constitution and makes sure that there will not be such external power to be misused in any steps of policy formulation. In the context of coal mining policy, the actors of policy is also assumed as possessing their own interest so that any output of policy will never be completely both ideal and rational. Both formal and informal output which involved in the process will bring about their agenda and their interest so that rent-seeking practice will be delivered in the sake of different interest. In order to give constraint in conceptual level, the perspective of rent-seeking in this research will be focused in using definition by Khan (2000). The definition is related to expenditure resource including the aspect of effort to create, distribute a transfer rents:

"Rent-seeking is the expenditure of resources and efforts creating, maintaining or transferring rents" (Khan, 2000:70).

This study uses theory of elites for the focus of study and policy character. Character of coal mining policy consists of the authority between local and central government in term of exploitation of permit policy and extra regulation of mining. Confirming this, theory of elites by Schumpeter is considered represents the conflicts of authority that mostly caused by political party and political elites that compete and oppose each other (Schumpeter, 1974). This elitism is later legitimated by democratic states in competing political market.

Anthony Downs developed the idea of Schumpeter and emphasized the theory of elites in term of economy (Downs, 1960; 1972) ${ }^{5}$ According to him, economists often considered that policy was made by government as an actor with pure altruistic nature. The consequences were that scholars were unable to put the "government" in economy theory based on premise that all people are considered to act rational as economy principles taught.

Other research on natural resources studied by Dasgupta (1998) revealed that the interest group of rent seekers have tried to obtain huge economy advantages with the minimum effort through policy lobby. Meanwhile, Clark (1998) explained that rent-seeking is the individual or group effort to increase income through government regulation. A research by Little (2002) gave more insight on how the government allocates the wealth parallel with the emerging of rent seekers. The wealth allocation emphasizes and confirms on why this policy study must use the approach of rent-seeking.

Other studiy on rent-seeking in coal mining business were organized by Syam Hadijanto (2014), and Asim Mehmood (2014). Morse (2002) and World Bank have reported the benefits was gained not by the businessmen but also the politicians and military officials. Hadijanto (2014) has revealed that the main factors on rent-seeking problem were the mismanagement od autonomous governance delivery and the less empowered on issuing lisence on mining management. In Pakistan, the similar froms of rent-seeking were mainly executed in three different proxy namely corruption, bribing, and lobbying (Mehmood, 2014).

\footnotetext{
5 This concept believes that any government's action would be the part of economic variables which is decided with political consideration. In term of policy, the proper function of government is to maximize social welfare (Downs, 1957: 135)
} 
Result of research was also reported by R. Torvik (2002) in term of rent seeking on natural resource. It has reported as follows: (1) the more natural resources provided in an area there were more activity on rent-seeking contests, so that there were less productive and competitive companies operate the business and more negative externalities occured, (2) more people involved in rent-seeking activity have raised the number of inefficient economics activities that reduce the average income of local people, and (3) the increase of companies on natural resource on contrary will decrease the total income and welfare level of community.

\section{Research Method}

Approach used in this research was case study in which the research used the strategy of explorative case study to the rent seeking in policy. The case study is well known as the most common approach applied in research policy with mostly using qualitative data in rent seeking practice of coal mining policy and very small portion using quantitative data in rent seeking impact. As defined by Yin (2003) that case study is merely focus on certain location instead of mass observation in numerous locations. Case study is capable to provide questions of "how" and "why". That is different with the data obtaining from survey approach which only poses question of "what".

Researcher also revealed on how the process of rent-seeking by businessman actor and government via surveyors after law of Mineral and Coal Mining (UU Minerba) was issued in 2009. In order to be more focus in this research, researcher developed inductive logic steps as mentioned by Creswell (2010: 96) as follow: (1) researcher collected information from in-depth interview and participative observation, (2) researcher asked opened questions to informants and provide recording and transcripts, and (3) researcher analyzed the data based on themes and categories and, (4) researcher figured out the common patterns, generalization or theories from those themes and categories, and (5) researcher pointed out the generalization or theories from literatures and personal experiences.

\section{Result and Discussion}

The findings already answered the research question. Three most prevalent findings in the study were: (i) the role of third person who played prominent roles in delivering the interest and determined the output of policy, (ii) bargaining power of the businessman to get access in penetrating the bureaucracy through bribing, and (iii) the role of bureaucrates in manipulating regulation to accommodate their interest through extra regulation making.

One of important factors in Indonesia mining sector management is the availability of accurate and real time database on export import production. Unfortunately the Directorate General of Mineral and Coal as the official institution which has a responsibility to maintain database is unable to provide the database. This institution has an assignment to control the export activity and provide production data through database. The inaccuracy of data leads to the different data which is discovered by the Team of State Revenue Optimalization (SRO). The estimation of economic loss from royalty (royalty payment and fixed fee) was reported by Indonesia's Corruption Eradication Commission (KPK) while inspecting the holders of 
KP/IUP/PKP2B/KK.

In the other hand, another different number of exported coals are reported by using data from surveyor's report (SR). The report is submitted by surveyors to the Directorate General of Foreign Trade. The analysis from the data shows that there is big dispute about unpaid royalty and fixed fee. During 2010 and 2012, according to the data of the Ministry of Trade of Republic of Indonesia, the unpaid payment of royalty/DBHD was estimated about US\$ 1.224 billion. As shown in table 1, the amount of unpaid royalty by coal companies was reported for 2010-2012. Even though the estimation of economic loss caused by rent-seeking was taken place, the exact number of the difference was difficult to explain. This study also stated that the amount of the unpaid payment was estimated about US\$24.661 million from 180 coal mining companies in 2011. ${ }^{6}$

\section{Surveyor's Data Manipulation on Exported Coal}

The case of surveyor once became notorious since The Commision of Corruption Eradication (KPK) in 2012 evaluated the system of Non-Tax State Revenue (PNBP) in mineral and coal mining subsector (minerba). In this study KPK had found the state economic loss was caused by inefficient system of royalty payment from 37 Mining Concession (MC) and 74 Coal Mining Agreement (CMA). The result of KPK study also reported that the state loss from their recent audit held by the Team of State Revenue Optimalization (SRO) was 6.7 trillion rupiah during the period of 2003-2011 from unpaid royalty. The potency of other state loss from 198 coal mining companies was US\$ 1,224 billion during the period of 2010-2012. The additional data shows the amount of unpaid royalty of 180 companies was US\$24,661 million in the year of $2011 .^{7}$

The result shows potency of unpaid royalty and fixed fee. The unpaid payment also causes a reasonable amount of state loss. Based on data provided by surveyor's report issued by Directorate General of Foreign Trade, the data of dispute of unpaid royalty is as follow:

\footnotetext{
${ }^{6} \mathrm{KPK}$, review report on coal and mineral receiving system, 2013.

7 KPK, review report on coal and mineral receiving system, 2013.
} 
Table 1. Dispute of Unpaid Royalty of Coal Company in 2010-2012

\begin{tabular}{c|c|c|c|c|c}
\hline No. & $\begin{array}{l}\text { Names of } \\
\text { Exporter }\end{array}$ & $\mathbf{2 0 1 0}$ & $\mathbf{2 0 1 1}$ & $\mathbf{2 0 1 2}$ & $\begin{array}{l}\text { Unpaid Royalty } \\
\text { (USD) }\end{array}$ \\
\hline 1. & $\mathrm{~A}$ & $85,561,484,43$ & $208,793,052,86$ & $63,904,546,46$ & $358,259,083,75$ \\
\hline 2. & $\mathrm{~B}$ & $130,066,673,02$ & & $44,075,856,58$ & $174,142,529,60$ \\
\hline 3. & $\mathrm{C}$ & $79,580,100,85$ & & $62,333,767,52$ & $141,913,868,37$ \\
\hline 4. & $\mathrm{D}$ & $30,816,363,18$ & & $76,894,285,50$ & $107,710,648,69$ \\
\hline 5. & $\mathrm{E}$ & $36,140,611,14$ & $9,165,300,27$ & $1,005,443,10$ & $46,311,354,51$ \\
\hline 6. & $\mathrm{~F}$ & & & $27,743,820,25$ & $27,743,820,25$ \\
\hline 7. & $\mathrm{G}$ & $9,507,617,44$ & & $18,205,820,25$ & $27,713,437,53$ \\
\hline 8. & $\mathrm{H}$ & & $14,165,777,55$ & $7,997,601,86$ & $22,163,379,41$ \\
\hline 9. & $\mathrm{I}$ & $5,774,356,04$ & $7,946,951,87$ & $4,215,405,56$ & $17,936,713,46$ \\
\hline 10. & $\mathrm{~J}$ & $9,302,082,80$ & & $7,387,856,83$ & $16,689,939,63$ \\
\hline 11. & $\mathrm{~K}$ & & $115,740,015,64$ & & $15,740,015,64$ \\
\hline 12. & $\mathrm{~L}$ & $5,617,461,42$ & $7,451,059,11$ & $2,258,038,16$ & $15,326,558,70$ \\
\hline 13. & $\mathrm{M}$ & $12,836,850,28$ & & & $12,836,850,28$ \\
\hline 14. & $\mathrm{~N}$ & & & $11,320,767,19$ & $11,320,767,19$ \\
\hline 15. & $\mathrm{O}$ & & $5,524,314,07$ & $2,885,559,85$ & $8,409,873,92$ \\
\hline 16. & $\mathrm{P}$ & $8,118,423,85$ & & & $8,118,423,85$ \\
\hline 17. & $\mathrm{Q}$ & $3,802,335,00$ & & $4,015,354,92$ & $7,817,689,92$ \\
\hline 18. & $\mathrm{R}$ & $6,967,160,86$ & & $657,700,54$ & $7,624,861,41$ \\
\hline 19. & $\mathrm{~S}$ & & & $6,882,881,97$ & $6,882,881,97$ \\
\hline 20. & $\mathrm{~T}$ & & $5,801,061,27$ & & $5,801,061,27$ \\
\hline 21. & Lain-Lain & $62,383,689,78$ & $72,815,990,73$ & $48,549,168,99$ & $183,748,849,50$ \\
\hline & Total (198 & $486,475,210,10$ & $347,403,523,37$ & $390,333,875,37$ & $1,224,212,608,84$ \\
\hline company & & & & \\
\hline & & & &
\end{tabular}

Source: Directorate General of Foreign Trade, 2012

The loss of revenue was stated by Ali Maskur Musa, the former member of Supreme Audit Agency (BPK). He conclued that state was suffered from losing revenue. it was about 180 trillion rupiah annually from oil sector, forestry, mineral, and coal. This fact based on BPK findings also confirmed that the mismatch of export import activity document is significant in oilm mineral, and coal mining in three institutions namely Ministry of Trade of Republic of Indonesia, The Ministry of Energy and Mineral Resources of the Republic of Indonesia, and Directorate of Tax and Customs. The loss revenue was possibly caused by the lack of law enforcement in natural resource and the lack of regulation management in such sectors (KPK, 2012).

The huge amount of economic loss can be estimated by the data provided by surveyor. This fact also explains that the role of surveyors in coal mining business is very essential. Surveyors should be the mediator between government and business in order to verify exported coal product, but they fails to provide assistance. They existence is officially constructed by central government, but in fact the service of surveyors in exported coal verification process is paid by coal mining companies in the sake of "principle of benefit/azas manfaat". At this point, it was crustily clear that export data can be easily manipulated. The 
role surveyor is very important to deal with rent-seeking coal and verification. ${ }^{8}$ The role is also including research and agreement validation checking on the validity of destination, port, state and port destination, value of export FOB (free on board), mining product assessment document, paid royalty, shipping time and this is why government become really subjected to the existence of surveyor data because government can not provide their own export database. The consequences are the data can be easily manipulated since the service was paid by local business people.

\section{Self Assessment Method: The Beginning of Problem}

Basically the obligatory to pay the royalty and fixed fee is managed by the business people (self-assessment). The process of PNBP estimation in mineral and coal mining is unsprayed in mining process and mineral and coal loading. In the mining process, planning and realization or selling should be paid by government. And the other way around, government should provide sufficiently accurate in term of volume and quality of mineral and coal. The amount of PNBP Mineral and coal should be paid by mining company owners based on information in the field. The information is including loading to mining cave, stockpiling, and loading to ship. In this case, government as the official who receive PNBP has no information at all. The information was collected in KK/PKP2B/IUP. The absent information will badly impact and cause inaccuracy in estimation process of PNBP in mineral and coal mining.

The weakness of method named self assessment is also mentioned by surveyor through an interview with Sukamto from PT. SI:

"Payment for surveyor was paid by exporter so that negotiation payment is intervened by company. A big coal exporter (like) PT. TEC is a loyal costumer for us PT. SI, we have deal in top level to advise anything technical...About mark up (and mark down) in quality and quantity was possible because nobody (institution) observing the process. "

(Sukamto, a surveyor, 10 July 2014).

Inaccurate data estimation of mineral and coal volume was caused by the several factors namely: 1) no rechecking by government in estimating volume and quality of mineral and coal by surveyor, causing difference amount comparing to government data; 2) minimum examination in shipping process; 3) conflict of interest among surveyors; 4) no access to surveyor's report by Directorate General of Mineral and Coal; 5) the location of ports and controlling is scattered for 71 ports, 604 ships, 111 shipping companies 929 shipping routes; ; and 6) overlapping regulation of the Ministry of Trade of Republic of Indonesia in mineral and coal mining management.

Surveyor companies have an authority in technical checking for the export of mining product. The task of surveyors is mostly in verifying and technically checking before loading of the

\footnotetext{
${ }^{8}$ See the Decree of Trade Minister/Permendag No. 14/M-DAG/PER/5/2008 about verification and technical tracing of mining export product including coal (3 verse (4)). The surveyorys were hired and paid paid by coal mining corporations. Furthermore, surveyor is legally arranged by the Decree of Minister of Trade Number 550/M-DAG/KEP/5/2012 that mentions the List of Official including PT. SI as Surveyor Verificator.
} 
exported coal. The procedure of surveyor company procurement was regulated by the Directorate General of Foreign Trade 9

Table 2. The Difference of Revenue Data in 2009 (USD)

\begin{tabular}{c|r|r|r}
\hline Cash Flow & \multicolumn{1}{|c|}{ Company } & Government & \multicolumn{1}{c}{ Difference } \\
\hline PPh & $1,109,956.93$ & $1,294,089.79$ & $-272,941.16$ \\
PBB & $6,281.92$ & $2,690.69$ & $2,879,00$ \\
Royalty & $938,167.18$ & $958,992.68$ & $-20,825.50$ \\
PHT & $215,581.62$ & $248,382.03$ & $-32,800.41$ \\
Iuran Tetap & $2,368.56$ & $2,273.38$ & 95.14 \\
Deviden & $63,063.72$ & $63,063,72$ & 0 \\
\hline Total & $2,335,419.93$ & $2,569,492.28$ & $-323,592.92$ \\
\hline
\end{tabular}

Source: Reconciliation on Extractive Industry, Transparancy Initiative Indonesia, 2013

The tasks of surveyors on technical assessment are relatively important. The activities are including: (1) reporting the verification report in surveyor's report (SR) with analysis quality of mineral composition; (2) issuing SR in 24 hours after checking; (3) submitting the area coverage while verifying free area; and (4) reporting SR through INSW website and portal.

Table 3. List of Surveyor in Mineral and Coal Shipping

\begin{tabular}{c|l|c}
\hline No. & \multicolumn{1}{|c|}{ Company } & Area Authority \\
\hline 1. & PT. Sucofindo & 27 provinces \\
\hline 2. & PT. Surveyor Indonesia & 21 provinces \\
\hline 3. & PT. Carsurin & 9 provinces \\
\hline 4. & PT. Geo Service & 9 provinces \\
\hline 5. & PT. Citra Buana Indoloka & 9 provinces \\
\hline
\end{tabular}

Source: Minister of Trade's Decicion Number 388/M-DAG/KEP/2008

\section{Rent Seeking Potency by Means of Data Manipulation}

The data provided by surveyors are easily manipulated because the cost on services of surveyor is paid by mining companies. In certain cases, government has no bargaining power in possessing real data. Mostly data are manipulated in coal production based on the order of mining companies to maximize profit. Companies are fully aware that they can maximize it through lobbying and bribing. Furthermore, cost of rent-seeking should be "maintained" for those who have power in The Ministry of Energy and Mineral Resources of the Republic of Indonesia and Ministry of Trade of Republic of Indonesia.

Coal data manipulation during the export process is taken places at least in these three different levels as follow:

\footnotetext{
${ }^{9}$ Requirement of surveyors: possessing permit of Survey Service (SIUJS); experience as surveyor on mining product at least 5 years; office and branch office in the area; certified technical experts as verificator, drafter, laboratory analyst; possessing 3 sites of laboratory in term of mining product.
} 
1. Draught survey during loading the coal to the barge/tongkang in jetty. Manipulation was made in number of measuring weigh.

2. While the barge/tongkang was ready to board, during this time manipulation was made in term of quality of the coal.

3. During the transfer process from barge/tongkang to the mother vessel. Manipulation was made in both numbers of measuring weigh and coal quality.

Surveyors surely play the important role in making surveyor's report (SR) in term of coal selling export by mining company. All of the cost during process of survey including report and cost of laboratorium were paid by coal mining company. Since the companies are fully in charge, they are in open position to drive their own interest against surveyor's report (SR). That was merely because SR contained of all data needed to send to the buyer and non-tax state revenue (PNPB) payment of coal. During coal loading from tongkang in jetty, the role of surveyors in making mark down/mark up loading tonnage is significantly important for mining companies.

The method of mark down and mark up of weight by surveyor technically depends on the barge size and condition of the river. Interview with with surveyor reported that the barge size of 300 feet would make surveyor easily manage the mark down data of coal. Meanwhile the barge size of 270 feet will ease their effort of mark up. River condition also makes contribution in this process. Mark down tonnage is easier during the rising water in the river, compared when the water is recedeing. The difference of number is about $20 \%$ as decided by negotiation of both sides. ${ }^{10}$

While the barge was transferring to mother vessel the process need certification from COA (Certificate of Analysis) in term of chemical quality. The result of the certifícate was also adjusted by the conditions demanded by the buyers. Some chemical parameters were added in the COA certificate including ash, sulfur, $\mathrm{HGi}$, and calories. Those parameters must be adjusted in term of quality and price standards. When barge was finished transferring coal load to mother vessel, there will be another measurement needed. In this step, another actor is involved. The ship captain from transporter is hired by the imported companies (buyers). In exporting the coal to the final destination, the captain has an authority to sign the papers about coal load and quality. The certain method is used a compromise and make a deal with the captain. The most common method is a party that is held to entertain the ship captain and crews. The entertaining strategy is well-known as "party and prostitute" in the mother vessel. When the party was over, basically the paper surveyor's report with mark up quality will be signed and the data was fully manipulated.

In term of prostitution, the similar result was confirmed in a research in Tanzania by Kitula (2006, in Siburian, 2015) that shown the similar situation. The new consession of gold mining in Geita District initiate the new phenomena of migration from the rural area. People searched for a new job not only the men who hoped for work in mining area but also women

10 interview with Mr. TG, a director of PT. IBM and Mr. H, a surveyor from PT. SI, 4 March 2016. 
who wish to have job from the mining project. Kitula (2006) reported that the migrant group increased the number of criminal and women ended up their job seeking in prostitution.

To save the case of "party and prostitute" in manipulating the ship's crew, company would give sum of money to bribe the officers from Sea Police Squad. The interview with Temmy, the Director of PT. BI Trading Company reconfirmed the same stories.

"Mark up and mark down of coal load and quality coal never find obstacle... (because) no certain institution take part to observe surveyors... When they have loading and barge is done and loading coal ke mother vessel, the checking from transporter and buyer representative was alwys easy-but difficult...one day before the inspection usually (we) sent some prostitutes and liquor to negotiate... But also we have to safe and bribe the police officer no to get caught (razia)...."11 (Interview, 4 December 2014)

The data taken from surveyor report is actually not valid. The report was easily manipulated and published in two different versions. Most of the times SR as reported by surveyors are made into "double report". The first version of report was made for buyer mark-up in quality and stack of coal for export purpose. The second version was the report for government which including mark-down in quality and production amount. The interview with Loka, a surveyor from PT. SC also confirm with the similar information as follow:

"Some big companies used PT. SC as surveyors because they (the surveyors) know so well to understand what buyer need. Also that payment will be charged to exporter. We have to adjust the report (different report) but only $20 \%$ from the maximum (the difference). The number is our tolerance... and other surveyors do the same thing"

(interview, 18 November 2013).

The difference between the data is used to pay for the cost of rent-seeking. The cost is not included in production cost but it is provided through manipulation by surveyor. ${ }^{12}$ The phenomena of double report and data inconsistency are actually become concern of many stakeholders. Inaccurate data is one of three important indicators in this research namely: data manipulation, regulation gap misuse, and policy inconsistency. The two first main factors of state loss in natural resource sector are namely ineffective regulation and moral hazard of policy actors. These also are reflected in a number of data manipulation, transfer pricing, cost of mark-up, misuse of tax treaty, manipulation of self-assessment, and regulation dispute.

As on of misuse evidence was the report of $\mathrm{BPK}^{13}$, according to researcher of mining policy, Marwan Batubara, he stated that export coal data from the business association convinces having number of more than 500 million tons. But offical data released on exported coal was only 380 millions ton in 2013. The difference came from several unreported export, it might

\footnotetext{
${ }^{11}$ For additional information, see http://www.newsliputan6.com/read/146154/Pelacur_ditangkap_saat beroperasi_diataskapal.

${ }_{12}$ Interview with Mr. H from PT. CRGL, 22 April 2016.

13 Marwan Batubara, Opini Kompas, 7 February 2012.
} 
be ilegal or missed from monitoring. ${ }^{14}$ In the other hand, effort from local government is less than what is actually needed in observing and obtaining tax. ${ }^{15}$

\section{Data Manipulation: Mark Up and Mark Down of Exported Coal}

Rife institutions are getting involved in the case of surveyors. That is why it is difficult to clearly mention the actors as individuals. Even the role of government institution causes the lack of surveyor control. This also caused a reasonable amount of state loss for about 14 trillion rupiah from data inconsistency with mark-up and mark-down in the sake of interest in rent-seeking. The lack of law enforcement also causes rent-seeking between businessmen in coal with surveyor. This situation makes the entity of rent-seeking brings to the collusion supported by regulation as mentioned in Ministry of Trade of Republic of Indonesia regulation (Permendag) Number 14/M-DAG/PER/5/2008.

The role of surveyor in determining data is quite complicated. The result of surveyor's assessment will determine the sustainability of operational and mining safety. This task demands huge responsibility and not just the matter of the number. That is easily can be manipulated. The assessments of surveyors are sets of information that determine the process of mining operational. In the other hand, all surveyors must posseses technical certificate published by related institution. ${ }^{16}$

Table 4. Rent-seeking Practice Related to Surveyor's Role

\begin{tabular}{|c|c|c|}
\hline No. & Process & Analysis \\
\hline 1. & $\begin{array}{l}\text { Data } \\
\text { manipulation/ } \\
\text { Regulation }\end{array}$ & $\begin{array}{l}\text { 1. Mark up/mark down on coal quality and quantity in surveyor's } \\
\text { report (SR) during draught survey (mark up/down up to } 20 \% \text { ). } \\
\text { 2. Mark up/mark down on coal quality and quantity in surveyor's } \\
\text { report (SR) in Mother Vessel. Instrument used was the lobbying } \\
\text { against inspection team of buyer during the departure of mother } \\
\text { vessel to the port of destination. }\end{array}$ \\
\hline 2. & $\begin{array}{l}\text { Misuse of } \\
\text { regulation }\end{array}$ & $\begin{array}{l}\text { The use of regulation gap based on official regulation by Ministry of } \\
\text { Trade of Republic of Indonesia number 388/2008 about } \\
\text { self-assessment in verifying export coal. Used by business sector to } \\
\text { obtain mark up and mark down based on buyer needs. The surveyor's } \\
\text { report (SR) was fully manipulated and further used as estimation of } \\
\text { government non-tax income (PNPB). It was reported by KPK that the } \\
\text { estimation of state loss by auditor team was } 6.7 \text { trillion rupiah during } \\
\text { 2003-2011. }\end{array}$ \\
\hline 3. & $\begin{array}{l}\text { Inconsistence } \\
\text { of policy }\end{array}$ & $\begin{array}{l}\text { 1. Mismatch on document of coal export in } 3 \text { institutions (Ministry } \\
\text { of Trade of Republic of Indonesia, The Ministry of Energy and } \\
\text { Mineral Resources of the Republic of Indonesia, and Directorate } \\
\text { of Tax and Customs) } \\
\text { 2. The absence of check and balance since the elimination of SKAB } \\
\text { by The Ministry of Energy and Mineral Resources of the } \\
\text { Republic of Indonesia }\end{array}$ \\
\hline
\end{tabular}

Source: Primary data analysis, 2016

\footnotetext{
${ }^{14}$ Marwan Batubara, Majalah Pajak, 2 July 2014.

15 Marwan Batubara, Opini Kompas, 7 February 2012.

${ }^{16}$ Mr. Aan Budiono, a former surveyor coordinator during 2004-2007.
} 
A review was made by Migas Review (5 February 2015) that Chief of Natural Resource Research Team from KPK, Dian Patria, reported all of mining surveyor contributed in state economic loss. The estimated loss was 6.000 of mark down into 4.000 in term of real production amount. Meanwhile, one of instruments of regulation was issued by government when they abolish Reference of Commodity Origin (SKAB) which issued by local government. ${ }^{17}$ This elimination was considered as an inconstitutional policy and then was rejected based on two reasons namely: (1) the loss of revenue by local government and (2) the fact that government no longer posseses production database as basic number for estimating royalty by origin area. The absence of database on number is to be manipulated.

Another source confirmed that PT. Sucofindo there were hundreds of trilion rupiah of mining royalty unpaid. The mining companies hired the "shadow" surveyor company that possessing no integrated data with government. The head of management and system PT. Sucofindo stated that at least two problems in mining sector mining namely "the leak of oil and gas" and "the leak of tax". He also stated only about 25 percent of tax would be paid for the state (Kompas, 16 September 2014).

\section{Government Initiation in Creating Rent Seeking}

The main role of government in creating rent-seeking is seen when the surveyors are the third party and being legalized by state. The role of surveyors is legalized with certain policy issued from regulation of Ministry of Trade of Republic of Indonesia number 384/2000, it is about verification of mining, mineral, and coal product by surveyor. The procurement is made directly to several surveyors as verification officers to technically track the export product of mining coal. The surveyor companies are PT. Sucofindo, PT. Surveyor Indonesia, PT. Carsurin, PT. Geoservices and PT. Citra Buana Indoloka. This decision is made without procurement process. Interesting contestation is occurred between government actors and businessmen in creating rent-seeking by exported coal data manipulation by surveyor. This case causes the huge loss to the state and the public. Nevertheless government makes this occur by letting the exported data provided solely by surveyor.

\section{Reference}

Creswell, J. W. (2007). Research Design: Pendekatan Kualitatif, Kuantitatif dan Mixed. Pustaka Pelajar: Yogyakarta.

Evaquarta, R. (2008). Business and Political Actor Relationship in Indonesia's Local Autonomy Project: A Comparative Study on Batam City and Kutai Kartanegara Regency. Australian Political Studies Assocation Conference: Brisbane.

Grindle, M. S., \& Thomas, J. W. (1986). Public Choice and Policy Change: The Political Economic of Reform in Developing Countries. Princenton University Press: New Jersey.

Hadijanto, S. (2014). Kajian Sosio-Yuridis terhadap Munculnya "Obral Izin" Pertambangan Pasca Pemilukada dalam Era Otonomi Daerah (Studi di Kawasan Pertambangan Batu Bara

\footnotetext{
17 Based on the Decree by Directorate of Mineral and Coal Number 02.E/30/DJD/2012 about Reference of Commodity Origin (SKAB), and Number 03.E/30/DJD/2012 about Payment and Contribution of Third Party.
} 
Kota Samarinda). Fakultas Hukum Universitas Widyagama: Malang.

Howlett, M., \& Ramesh, M. (2007). Studying Public Policy: Policy Cycles and Policy Subsiystems. Oxford University Press: Oxford.

Jomo, K. S. (Ed). (2013). Industrialising Malaysia: Policy, Performance, Prospect. Routledge: London. https://doi.org/10.4324/9780203021910

Khan, M. H., \& Jomo, K. S. (Ed). (2000). Rents, Rent-Seeking and Economic Development: Theory And Evidence in Asia. Cambridge University Press: Cambridge. https://doi.org/10.1017/CBO9781139085052

KPK. (2013). Laporan Kajian Sistem Penerimaan PNPB Mineral dan Batubara.

Krueger, A. O. (1974). The Political Economy of the Rent-Seeking Society, The American Economic Review, 64(3). https://doi.org/10.3386/w3340

Krueger, A. O. (1990). Goverment Failures in Development in Jeffrey Frieden et al. (Ed). 1991, Debt, Development, and Democracy: Modern Political Economy and Latin America: Theory and Policy. Westview Press: USA.

MacIntyre, A. (2000). Funny Money: Fiscal Policy, Rent-seeking and Economic Performance in Indonesia in Mushtaq H. Khan \& Jomo Sundaram (Ed). 2000, Rents, Rent-Seeking and Economic Development: Theory and Evidence in Asia. Cambridge University Press: Cambridge.

Mehmood, A. (2014). Effects of Rent-Seeking and its Three Forms (Corruption, Bribery and Lobbying) on Entrepreneurship (A Descriptive Study on Pakistan). Umea School of Business and Economics: Pakistan.

Morse, J. M., \& Maddox, L. J. (2014). Analytic Integration in Qualitatively Driven (QUAL) Mixed and Multiple Methods Designs dalam Flick, Uwe (Ed). (2014). The Sage Handbook of Qualitative Analysis. Sage: London.

Parsons, W. (2008). Public Policy: Pengantar Teori dan Praktik Analisis Kebijakan. Kencana: Jakarta

Paskarina, C. A. M., \& Madung, O. G. (Ed). (2015). Berebut Kontrol atas Kesejahteraan: Kasus-Kasus Politisasi Demokrasi in Tingkat Lokal. Polgov \& PCD Press: Yogyakarta.

Torvik, R. (2002). Natural Resources, Rent-Seeking And Welfare, Journal of Development Economics, 67(2). https://doi.org/10.1016/S0304-3878(01)00195-X

Tullock, G. (1968). The Origin of Rent-Seeking Concept, International Journal of Business and Economic, 6(1).

Tullock, G. (2005). Public Goods, Redistribution and Rent Seeking. The Locke Institute: George Mason University. https://doi.org/10.4337/9781845424688

Yin, R. K. (2003). Studi Kasus: Desain \& Metode. Rajawali Press: Jakarta. 
Yustika, A. E. (2011). Ekonomi Politik: Kajian Teoritis and Analisa Empiris. Pustaka Pelajar. Yogyakarta.

\section{Copyright Disclaimer}

Copyright for this article is retained by the author(s), with first publication rights granted to the journal.

This is an open-access article distributed under the terms and conditions of the Creative Commons Attribution license (http://creativecommons.org/licenses/by/4.0/). 